\title{
Nurses' moral deliberation in the child care process
}

\author{
Deliberação moral de enfermeiros no processo de cuidar de crianças \\ Deliberación moral de los enfermeros en el proceso de cuidado de los niños
}

\section{Deisy Vital dos Santos' \\ ORCID: 0000-0002-2312-3586}

Darci de Oliveira Santa Rosa' ORCID: 0000-0002-5651-2916

\section{Elma Lourdes Campos Pavone Zoboli"}

ORCID: 0000-0002-7324-5389

Lydia Feito Grande III ORCID: 0000-0002-9300-5470

'Universidade Federal da Bahia. Salvador, Bahia, Brazil. "Universidade de São Paulo. São Paulo, São Paulo, Brazil.

"' Universidade Complutense de Madrid. Madrid, Espanha.

How to cite this article: Vital-Santos D, Rosa DOS, Zoboli ELCP, Grande LF. Nurses' moral deliberation in the child care process. Rev Bras Enferm. 2019;72(0):197-203. doi: http://dx.doi.org/10.1590/0034-7167-2018-0423

\section{Corresponding Author: \\ Deisy Vital dos Santos \\ E-mail: deisy@ufrb.edu.br}

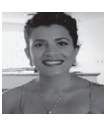

Submission: 06-11-2018

Approval: 09-23-2018

\section{ABSTRACT}

Objective: To understand the nurses' moral deliberation in the face of an ethical problem involving breastfeeding. Method: Qualitative study based on the methodological theoretical framework of deliberative bioethics. Data collection was through a vignette-based interview and results were organized by thematic analysis. Results: Nurses tend to take over intermediate courses of action, although extreme courses of action are found as well. Final considerations: When they tend to take extreme courses of action, nurses approach decisions focused on the child welfare to the detriment of the mother's need as a working woman.

Descriptors: Bioethics; Child Health; Family Nurse Practitioners; Breastfeeding; Decision Making.

\section{RESUMO}

Objetivo: Compreender a deliberação moral de enfermeiros diante de um problema ético envolvendo o aleitamento materno. Método: Estudo qualitativo, fundamentado no referencial teórico-metodológico da bioética deliberativa. A coleta de dados foi através de entrevista orientada por vinheta e os resultados foram organizados por análise temática. Resultados: Os enfermeiros tendem a assumir cursos de ações intermediários, todavia, são encontrados cursos de ação extremos. Considerações finais: Quando tendem a cursos de ação extremos, os enfermeiros acercam-se das decisões voltadas para o bem-estar da criança, em detrimento das necessidades da mãe, enquanto mulher trabalhadora.

Descritores: Bioética; Saúde da Criança; Enfermeiros de Saúde da Família; Aleitamento Materno; Tomada de Decisões.

\section{RESUMEN}

Objetivo: Comprender la deliberación moral de los enfermeros que enfrentan un problema ético relacionado con la lactancia materna. Método: Investigación cualitativa, basada en el marco teórico metodológico de la bioética deliberativa. La recolección de datos se realizó mediante una entrevista basada en viñeta y los resultados se organizaron mediante el análisis temático. Resultados: Los enfermeros tienden a tomar cursos de acción intermedios, sin embargo, se encuentran cursos de acción extremos. Consideraciones finales: Cuando tienden a tomar cursos de acción extremos, los enfermeros abordan las decisiones sobre el bienestar del niño, en detrimento de las necesidades de la madre como mujer trabajadora. Descriptores: Bioética; Salud del Niño; Enfermeros de Familia; Lactancia Materna; Toma de Decisiones. 


\section{INTRODUCTION}

In bioethics and nursing, there are several methods for understanding decision making and analyzing ethical problems, and the Moral Deliberation (MD) model was elected for the present study ${ }^{(1)}$. Through this method, the demand for bioethics research can be satisfied and the empirical perspective can be integrated with the normative perspective in the construction of knowledge, thereby contributing for researchers' description and critic of results in order to propose courses of action for the practice ${ }^{(2)}$.

Moral deliberation is a method of analysis for practical decision making ${ }^{(3)}$. It is structured in the following phases: presentation of the clinical case and discussion of clinical and ethical aspects of the case; identification of moral problems presented; election of the main moral problem; identification of possible courses of action (extreme, intermediate and optimal); deliberation on the optimal course of action; final decision ${ }^{(1)}$. In the face of an ethical problem, this phases allow investigating the facts, values and duties for the deliberation about the optimal course of action in order to deal with the situation ${ }^{(2)}$. Each solution for the clinical case is considered as a course of action ${ }^{(1)}$.

From the MD, is expanded the uncertainty of professionals for an ethical decision making and the co-responsibility of multiprofessional teams. An appropriate approach to ethically complex situations enables considering the specific circumstances of each case $^{(4)}$. The results achieved are part of a dynamic and always unfinished process that is consequently subject to change and demands revisions and resumption ${ }^{(5)}$.

In the dimension of child health care, ethical problems may emerge, and the Family Health Strategy (FHS) can be a place of choice for nurses' deliberative analysis.

The models of care proposed by the Technical Area of Child Health and Breastfeeding (Portuguese acronym: ATSCAM) integrate promotion, surveillance, prevention and care actions into four priority lines of care: Promotion, Protection and Support of Breastfeeding; Violence Prevention and Promotion of the Culture of Peace; Incentive and Qualification of Growth Monitoring; and Development and Health Care of the newborn. For the provision of comprehensive child health care, actions and guidelines must be interrelated in practice ${ }^{(6)}$.

The lines of care are within the context of Primary Health Care (PHC) and promote the systematic monitoring of children under five years through the Community Health Agents Program and the FHS. They seek to develop a bond with families, user embracement, and the co-responsibility and resolution of services. In addition, there is the benefit of the action plan aimed at the main problems of the population with reference to the local reality ${ }^{(7)}$.

The growth and development of children should be monitored regularly in their early years and is part of nurses' and physicians' responsibility. The reinforcement of Exclusive Breastfeeding (EBF) stands out among the guidelines provided for this consultation ${ }^{(8)}$.

The World Health Organization (WHO) classifies breastfeeding in five ways, namely: Exclusive Breastfeeding (EBF); Predominant Breastfeeding (PBF); Breastfeeding (BF); Complementary Breastfeeding (CBF); and Mixed or Partial Breastfeeding (MBF). EBF is recommended until the sixth month of life of the infant. After this period, breastfeeding can continue until the child's two years of age in association with complementary feeding ${ }^{(9)}$. Animal milk (cow's milk diluted in water) or infant formula (processed milk) can be used for children who are not being breastfed ${ }^{(10)}$.

Issues involving the maintenance of breastfeeding have been the subject of several Brazilian studies based on different perspectives such as reproductive rights ${ }^{(11)}$, programmatic vulnerability and care ${ }^{(12)}$. There are also international studies focused on the concept of maternal autonomy ${ }^{(13)}$ and the relationship between Relative Autonomy and Breastfeeding Behavior ${ }^{(14)}$. However, no studies on the maintenance of EBF as an ethical problem in the child care process were found.

\section{OBJECTIVE}

To understand nurses' moral deliberation in the face of an ethical problem involving breastfeeding.

\section{METHOD}

\section{Ethical aspects}

This study complied with the ethical norms of Resolution $466 / 2012$ and was approved by the Research Ethics Committee of the Nursing School of the Universidade Federal da Bahia.

\section{Type of study}

Qualitative study based on the methodological theoretical framework of deliberative bioethics. Data collection with vignettebased interview (with an ethical problem) and results organized by thematic analysis.

\section{Methodological procedures}

\section{Study scenario}

The study had participation of 14 nurses $(\mathrm{N})$ working in the FHS, both in rural and urban settings in the municipality of Feira de Santana, state of Bahia.

\section{Data source}

The selection of interviewees was intentional with the perspective of reaching a heterogeneous group. For representing the variability of nurses in the FHS and by considering possible peculiarities interfering in the approach of the phenomenon under study, the following inclusion criteria were used: longer and shorter training time; sex; work area (rural setting and urban setting); and, in the case of women, having become pregnant while working at the Family Health Unit (FHU). The theoretical saturation of data was used to finalize the interviews, that is, interviews were finished after collecting the necessary material for understanding nurses' moral deliberation ${ }^{(15)}$.

Fourteen FHS nurses participated in the research, out of which 12 were female and two were male; ages ranging from 31 to 64 years. The time since graduation was between two and 32 years, and the working time in the FHS was between seven months and 18 years. 


\section{Collection and organization of data}

The data collection technique adopted was the vignette, which consists of a brief description of a given situation, where interviewees are invited to present their possible reactions, and the researcher is allowed to ask open or closed questions ${ }^{(16)}$.

The theme of the vignette (breastfeeding) was chosen from the frequency with which ethical problems were identified by nurses in the context of child health after completion of an inventory form in the quantitative phase of the study ${ }^{(17)}$. The following vignette was presented:

Mrs. JSM, registered with the FHS Z, was accompanied by nurse MC during family planning and later, in prenatal care. During prenatal care, she was advised from the first consultation on the role of exclusive breastfeeding until the sixth month of age for children's growth. After childbirth, she took the infant to Child Growth and Development Monitoring (Portuguese acronym: ACD) consultations with the same professional. When the child was two months old, Mrs. JSM asked the nurse for a recommendation of an artificial milk to feed the child, because she would go back to work and could no longer continue breastfeeding.

Interviews were conducted individually at Family Health Units and at the Municipal Health Secretariat, according to nurses' interest. After the end of the vignette exposure, the following question was asked: What would you recommend for solving the problem and why? The average duration of interviews was ten minutes.

Thematic analysis was used for organization of data because it is effective in direct and simple speeches ${ }^{(18)}$.

\section{Data analysis}

The theoretical-methodological framework for the analysis of results was based on the Moral Deliberation method, specifically in the stage of deliberation about duties ${ }^{(1)}$ from self-reports with participants' reactions to the vignette. Gracia's deliberative bioethics brings the analytical category of prudence. In the analysis of results based on this referential, mediating relations are unveiled. With the findings, it is possible to conduct a hermeneutic and problematizing dialogue that questions the presumptions of discourses. The objective is not to issue 'right' and 'wrong' judgments, but to trace trends in responses and reactions to the vignette, which favors awareness regarding the ethical sensitivity of actions and decisions ${ }^{(2)}$. In other words, there is deliberation about the findings.

\section{RESULTS}

\section{Courses of action}

From nurses' recommendations to solve the ethical problem presented in the vignette, the courses of action were grouped into six trends, namely: Guidelines for maintaining EBF; Involvement of the multidisciplinary team; Recommendation of the artificial/ animal milk name; Guidelines for guaranteeing labor rights; EBF guidelines; and Participation in pregnant women's group.

The Guidelines for maintaining EBF included courses of action such as: guidance on the correct way to express the breastmilk; store milk in refrigerator; guidance on hygienic care with utensils used for collection, storage and supply of milk to the child; guiding the child's caregiver regarding the form and times for offering the expressed breastmilk during the mother's working period; and take the child to the mother's work.

[...] I was going to try to keep the breastmilk, even if the child it is not breastfed directly. She expresses the breastmilk and offers it pasteurized [...]. (E14)

For no cost, the mother has her own milk. And it is stored at home, because if we recommend one [milk brand], it is very expensive, so they will not give, I don't recommend it, myself [...]. Because nobody can afford to buy a can, and that's it, so the ideal would be to store their own milk, put it in a water bath and feed the child. (E12)

Among the suggestions of Involvement of the multidisciplinary team, the figure of the doctor (not necessarily the pediatrician) and the nutritionist were highlighted, frequently mentioning the interdisciplinary consultation as a course of action adopted in nurses' practice.

[...] but artificial milk for me would be the last resource, or in cases where the mother cannot breastfeed at all, but this guideline of recommending names, because, you know, in fact, you're advising a formula. Thus, it must be medical advice. So, that would be an interdisciplinary consultation between the physician, the nutritionist and the nurse, at least that's how it happens in my unit. (E14)

The Recommendation of the artificial/animal milkname presented two courses of action: use of infant formula with predominance of the recommendation of two commercial brands (E3, E6, E7, E11); and use of animal milk (cow's milk, goat's milk). The recommendation was always combined with care guidelines on the use of these milks.

[...] / recommend either the [brand name] only, according to the patient's condition, many times, my patient cannot afford either of them, and it has to be the [brand name] only, l explain it's not so indicated because of constipation, but then, I do it, we adapt according to the patient's condition, it will also depend on the patient's condition. Always that typical Brazilian way, but there is no lack of support. (E3)

[...] I advise cow's milk, not cow's milk, I beg your pardon? Goat's milk, but goat's milk has no iron, is weaker, then, from six months on, it has to change for regular milk. It depends on the situation, each situation, depending on the person's condition, really, if there's no condition and she will introduce it anyway, we have to advise. (E9)

In the course of action addressing the Guidelines for guaranteeing labor rights, is considered the value of child welfare, as shown in the following excerpt:

[...] finding a way to maintain exclusive breastfeeding as long as possible, even if she goes back to work, that she negotiates with her employer the breastfeeding time, even by leaving early and making up for the time she is entitled to. To breastfeed her child [...]. (E11)

In EBF guidelines, the aim of the course of action is always to maintain a harmonious relationship with the mother and consequently, ensure that breastfeeding is offered to the infant. 
[...] sometimes, the mother asks for some milk, at least at night, so she can rest, when I see that I will lose the breastmilk, then, I go and encourage her to offer the other milk, so she can rest [...] at least a bottle in the middle of the night, the rest would be the breast, because she wants to rest, at least, this is a way for avoiding that she stops giving the breast during the day. (E1)

Only one nurse presented Participation in pregnant women's group as a course of action, as transcribed below:

[...] importance of the support group that she can attend to, I'm not sure if she is attending, in prenatal care, which is of the pregnant women's group, and the mothers' group, these are a routine of ours, here at the unit with support of the Family Health Support Center [NASF] staff, nutritionist, physiotherapist, who encourage exchange of experiences between mothers and pregnant women, who can help them to adhere to breastfeeding for the recommended time. (E10)

\section{Trend of nurses' courses of action}

The fundamental ethical problem chosen for analysis of the trend of courses of action was How to guarantee the child's proper nutrition without disregarding the mother's work needs?

The extreme courses of action were the following: insisting on maintaining exclusive breastfeeding (child welfare); and recommending the name of another artificial/animal milk (meeting the mother's work needs). These results are shown in Figure 1: carry on any of these suggestions, then what would I recommend? The artificial milk according to the child's age, in case [commercial brand milk] of the first semester, appropriate for the child's age, and observe if the child would have any reaction or not. (E6)

Employers' disregard and disrespect for labor rights give rise to feelings of helplessness and courses of action that seek to help working mothers with defending these rights, as shown in some speeches:

The mother needs to work, and unfortunately, this is out of the question, this is something that goes beyond us, these are laws, rules of each company, in some companies, when they work under the formal regime, there's the issue of maternity leave, but in others, there's not much respect for that. (E8)

At the end of prenatal care, I advise these mothers to continue working as long as they can until the end of their pregnancy, so they can spend the postpartum period with their child. So, I always advise these cases, even if at the end of pregnancy, some feel unwell. Then, we try to provide a medical certificate, advise her to hold on a little longer, talk to the employer, change the department, so they feel more comfortable, so they can be with their child a little longer. (E11)

However, in a discourse, labor rights served as justification for maintaining EBF:

[...] my thoughts are, the mother who is breastfeeding, she is entitled to at least four months, 120 days to return to work, so much so that some municipalities and companies are granting up to six months for the mother staying longer with her child, so, I see no reason for changing the breastfeeding of a two month old child. I would not do that, nor would I offer any other guidance. Exclusive breastfeeding, I am faithful to that. (E4)

The justifications for insisting on maintaining EBF are associated with scientific evidence about the benefits of this practice for children (nutritional, growth/development and affective aspects), as in the following statements:

Figure 1-Ethical problem, conflicting values and extreme courses of action, Feira de Santana, Bahia, Brazil, 2016

A participant justified the choice of the extreme course of action, as demonstrated in the excerpt below:

[...] it's the standard advised by the Ministry of Health that's written in the books, so I follow the norm that I have to follow, even knowing of the mother's need to work, because there are methods she can use to continue breastfeeding, even at two months, with no harm to the child, so the child is not affected [...]. (E13)

The following are among intermediate courses: offering guidance on expressing the breastmilk (child welfare); and seeking guarantee of labor rights (meeting the mother's work needs), as shown in this statement:

The first step, if she could bring the child to work in order to continue breastfeeding. If not, I would advise to express the breastmilk and leave it, then, the child's caregiver would put it in "water bath" and offer it at regular times. If after everything, she said she could not
First, because it has the appropriate substances for the good development of children, vitamins, minerals, urea, potassium, even water, after all, it's free, has the benefits of child immunization against some respiratory and digestive diseases, and other things. It will strengthen the child's jaw, benefits mothers too, with immunization against cervical cancer and breast cancer and others, that's why l am so pro breastfeeding. (E4)

Because I believe in breastmilk, not only in the matter of material food, the milk itself, but also in the aspect of physical contact, it is a whole context, [...] breastfeeding, the act itself, it has this eye contact, affection, touch, I believe in this set, in this food, whether physical or spiritual, I don't know if we can put it this way, this bonding [...]. (E1)

\section{DISCUSSION}

In seeking to understand nurses' moral deliberation in the face of an ethical problem in child health practice in the FHS, their deliberation tends towards intermediate courses of action. This finding 
is similar to results of a study conducted with nurses in São Paulo, who were facing an ethical problem involving an adult patient ${ }^{(19)}$.

In view of the conflict between the two values, child welfare versus meeting the mother's work needs, the concern to preserve the value of child welfare was predominant among interviewees.

A review study concluded that nurses' ethical decision making is complex. It involves the analysis and comparison of courses of action identified as possibilities from external and internal multidimensional elements by using scientific knowledge and ethical sensitivity in the construction of answers ${ }^{(20)}$.

This complexity was evident in the context of breastfeeding as part of child health, focus of the present study. The concept of reproductive right must be included as a guide for health professionals' practices with the intention of understanding breastfeeding as a psycho-sociocultural process and not only biological(11).

Extreme courses of action that prioritized the value of child welfare over the value of meeting the mother's work needs were presented by two study participants.

The ethical problem of the vignette implies the autonomy of the mother, but what does it mean? Is it possible to consider/accept this autonomy in face of the priority condition experienced by children? Is it possible to talk about the mother's autonomy given the urgency of depending on her job to support her child? In the bioethical perspective, yes. Canadian researchers, in a review study, formulated the following concept of mother autonomy in the context of breastfeeding: "the maternal ability to make autonomous decisions with use of their control, agency, independence and ethical reasoning preceded by maternal competence, availability of support, nature of environment and available alternatives in breastfeeding"(13).

In line with this concept, Brazilian authors warn about the need to frequently review and evaluate the professional practices that advocate breastfeeding regarding "how much autonomy is possible in relation to breastfeeding, and if people actually have conditions to make their decisions and have all the support they need in the decisions they make"(12).

In a study on the practice of EBF in southern Brazil was suggested the lack of conceptual clarity about EBF among investigated women, which demands the promotion of breastfeeding with the approach of beliefs and values by ensuring an effective dialogue and understanding with mothers ${ }^{(21)}$.

In a study on home visits in the context of child health, professionals (nurse and physician) demonstrated difficulty in accepting the mothers' refusal to breastfeed and showed authoritarian attitudes in defense of breastfeeding. However, aspects of value judgment and recognition of women as people should be analyzed for understanding their demands ${ }^{(22)}$.

The suggestion is to exchange frustration and anger for learning and dialogue by creating a space where users and professionals find practical and targeted ways to reduce the vulnerabilities of women and children ${ }^{(12)}$. Nurses, as part of the FHS team, are responsible for their clientele and involvement with the life history of each user, hence, they face the challenge of an ethical professional practice ${ }^{(23)}$.

When considering deliberative bioethics, the moral obligation is to "save" the two implicated values (of the child and the mother), since it is not possible to establish a universally validated hierarchy of values, nor is it acceptable to renounce important values.
That is, the values of child welfare and meeting the mother's work needs are equally essential. Thus, the ethically prudent option is to choose courses of action that protect and realize both values.

Labor issues involved in the breastfeeding practice are essential variables. In a study on the performance of FHU nurses in relation to the mother's return to work, were also found guidelines linked to the issue of the right to breastfeed children at work until their sixth month of age and expressing and storing breastmilk ${ }^{(24)}$.

However, as revealed in the speeches of some interviewees, in practice, labor rights are not fully respected yet. There is a fragile and difficult relationship "between the social world and the public universe of women's citizenship" in which legal norms that ensure gender equality are not implemented ${ }^{(11)}$.

The course of action participation in pregnant women's group can be a coherent strategy for solving the problem. In a study in the Republic of Chad, was found evidence of an association between motivational autonomy at the community level and the likelihood of exclusive breastfeeding ${ }^{(14)}$.

Guidance on starting artificial milk was a frequent course of action among respondents. This finding is consistent with results of a secondary data study from the National Demographic and Health Survey (Portuguese acronym: PNDS), in which consumption of infant formula was found in $23 \%$ of children under six months of age. In addition, the northeast region is one of two Brazilian regions where non-breast milk consumption was frequent in children under six months ${ }^{(25)}$.

Other accessible courses of action in the FHS context have not been explored, such as: knowing the family structure in order to trigger a collaborative network to meet the mother's demands; adding the father figure as a co-participant for promoting child welfare; and checking the existence/availability of a milk bank and home visits as singular spaces of care.

All courses of action presented for ethical problems in the context of child health should seek the preservation of conflicting values as much as possible, with the expectation of achieving the greatest welfare of those involved ${ }^{(3)}$. Even considering the possibility of making mistakes, it is necessary to seek ethically justifiable decisions and assume the consequences ${ }^{(5)}$. Since in nursing, the ethics of maximum is not limited to meeting the ethical/legal norms of the profession, but advances in the pursuit of users' highest welfare, the actions of nurses should be guided by the ethics of maximum and not merely the ethics of minimum ${ }^{(26)}$.

Electing prudent decisions in the face of ethical problems requires nurses' daily reflection, i.e., stop and think with a view to promoting and protecting the family nucleus' health as a unit of care, as advocated by the FHS and in the search for users' greatest interest.

\section{Study limitations}

The limitations of this study are associated with the scarce scientific production on the subject, which makes the discussion and comparison of results difficult.

\section{Contributions to the area of nursing, health or public policy}

The unpublished contributions of the findings contribute to advances in the nursing area, as they show new nuances of the care offered by nurses to children in the context of PHC. 


\section{FINAL CONSIDERATIONS}

Faced with an ethical problem in the context of child health, FHU nurses deliberate with the perspective of reconciling conflicting values (child welfare and meeting the mother's work needs). The trend of the courses of action presented is close to the intermediate sphere. When these actions tend to the extreme, there is an evident predominance of concern with the child welfare to the detriment of the mother's demands for labor issues.

The uniqueness of ethical problems in childcare is linked to the child's own vulnerability and the variables that structure and/ or disrupt the family, which requires nurses' deliberative skills, as this method is based on prudence.

It is expected that the new reflections presented in this study will be included in the work practice of Brazilian nurses and that the deliberative bioethics method will be shared among these professionals as a way of qualifying nursing care in the child care process.

\section{ACKNOWLEDGMENT}

Thanks to the Bahia Research Foundation (Portuguese acronym: FAPESB) for the scholarship grant.

\section{REFERENCES}

1. Gracia D. The Moral Deliberation: the clinical ethics method. presentation of a paediatric case. Med Clin [Internet]. 2001 [cited 2016 Dec 10];117(1):18-23. Available from: https://doi.org/10.1016/j.rcp.2015.09.004

2. Zoboli ELCP. The use of moral deliberation in empirical research in bioethics. Rev Iberoam Bioét [Internet]. 2016 [cited 2017 Jan 23];(2):1-19. Available from: https://doi.org/10.14422/rib.i02.y2016.006

3. Gracia D. Problems with deliberation. Folia Humaníst[Internet]. 2016 [cited 2017 Jan 08];(3):1-16. Available from: http://revista. fundacionletamendi.com/index.php/main/ficha/91

4. Nora CRD, Zoboli ELCP, Vieira MM. Ethical deliberation in health: an integrative literature review. Rev Bioética [Internet]. 2015 [cited 2017 Jan 13];23(1):114-23. Available from: http://dx.doi.org/10.1590/1983-80422015231052

5. Grande LF. Ética profesional de la enfermería: filosofía de la enfermería como ética del cuidado. Madrid: PPC; 2000.

6. Ministério da Saúde (BR). Secretaria de Atenção à Saúde, Área Técnica de Saúde da Criança e Aleitamento Materno. Gestões e gestores de políticas públicas de atenção à saúde da criança: 70 anos de história [Internet]. Brasília, MS; 2011 [cited 2016 Dec 03]. Available from: http:// bvsms.saude.gov.br/bvs/publicacoes/70_anos_historia_saude_crianca.pdf

7. Souza RS, Ferrari RAP, Santos TFM, Tacla MTGM. Pediatric Health Care: practice of nurses in the family health program. Rev Min Enferm [Internet]. 2013 [cited 2017 Feb 05];17(2):331-48. Available from: http://www.dx.doi.org/10.5935/1415-2762.20130025

8. Ministério da Saúde (BR). Secretaria de Atenção à Saúde, Departamento de Atenção Básica. Saúde da criança: crescimento e desenvolvimento[Internet]. Brasília, MS; 2012 [cited 2016 Dec 19]. Available from: http://bvsms.saude.gov.br/bvs/publicacoes/saude_ crianca_crescimento_desenvolvimento.pdf.

9. World Health Organization (WHO). Indicators for assessing infant and young child feeding practices: conclusions of a consensus meeting held 6-8 November. [Internet]. Washington, DC; 2007. [cited 2017 Jan 22]. Available from: http://www.who.int/nutrition/publications/ iycf_indicators_for_peer_review.pdf.

10. Ministério da Saúde (BR). Secretaria de Atenção à Saúde, Departamento de Atenção Básica. Saúde da criança: aleitamento materno e alimentação complementar. 2a ed. [Internet]. Brasília, MS; 2015 [cited 2016 Dec 23]. Available from: http://bvsms.saude.gov.br/bvs/ publicacoes/saude_crianca_aleitamento_materno_cab23.pdf

11. Moreira KFA, Nakano AMS. Breastfeeding: instintive? natural? the biological paragon $\mathrm{x}$ the reproductive rights In discussion. Rev Bras Enferm [Internet]. 2002 [cited 2017 Feb 24]; 55(6): 685-690. Available from: http://dx.doi.org/10.5935/0034-7167.20020052

12. Souza SDH, Mello DF, Ayres JRCM. Breastfeeding from the perspective of programmatic vulnerability and care. Cad Saúde Pública [Internet]. 2013 [cited 2017 Feb 15]; 29(6): 1186-94. Available from: http://dx.doi.org/10.1590/S0102-311X2013000600015

13. Hirani SA, Olson J. Concept Analysis of Maternal Autonomy in the Context of Breastfeeding. J Nurs Scholarsh [Internet]. 2016 [cited 2017 Feb 28];48(3):276-84. Available from: https://doi.org/10.1111/jnu.12211

14. Vaz A, Pratley P, Alkire S. Measuring Women's Autonomy in Chad and its Associations with Breastfeeding Practices Using the Relative Autonomy Index. OPHI Research in Progress series 44a [Internet]. 2015 [cited 2017 Jan 14];1-38. Available from: http://www.ophi.org.uk/ wp-content/uploads/OPHIRP044a.pdf

15. Fontanella BJB, Ricas J, Turato ER. Amostragem por saturação em pesquisas qualitativas em saúde: contribuições teóricas. Cad Saúde Pública [Internet]. 2008 [cited 2018 Sep 11];24(1):17-27. Available from: http://www.scielo.br/pdf/csp/v24n1/02

16. Polit DF, Beck CT. Nursing Research: Generating and Assessing Evidence for nursing practice. 8. ed. Philadelphia PA: Lippincott Williams \& Wilkins; 2008.

17. Santos DV, Santa Rosa DO, Zoboli ELCP, Freitas KS. Adaptation of the inventory of ethical problems to the child health context. Acta Paul Enferm [Internet]. 2016 [cited 2017 Feb 12];29(5):586-94. Available from: http://dx.doi.org/10.1590/1982-0194201600081

18. Bardin L. Análise de conteúdo. Lisboa: Edições 70; 2011. 
19. Zoboli ELCP, Santos DV, Schveitzer MC. Difficult patients in primary health care: between care and order. Interface [Internet]. 2016 [cited 2017 Feb 26];20(59):893-903. Available from: http://dx.doi.org/10.1590/1807-57622015.0500

20. Nora CRD, Deodato S, Vieira MMS, Zoboli ELCP. Elements and strategies for ethical decision-making in nursing. Texto Contexto Enferm [Internet]. 2016 [cited 2017 Feb 13];25(2):e4500014. Available from: http://dx.doi.org/10.1590/0104-07072016004500014

21. Souza CAM, Chaoul CO, Carmona EV, Higa R, Vale IN. Exclusive breastfeeding practices reported by mothers and the introduction of additional liquids. Rev Latino-Am Enfermagem [Internet]. 2015 [cited 2016 Dec 11];23(2):283-90. Available from: http://dx.doi. org/10.1590/0104-1169.0141.2553

22. Andrade RD, Santos JS, Maia MAC, Silva MAI, Veríssimo MLÓR, Mello DF. Home visit: care technology used by nurses to advocate for child's health. Texto Contexto Enferm [Internet]. 2015 [cited 2016 Dec 17];24(4):1130-1136. Available from: http://dx.doi.org/10.1590/0104-0707201500000120015

23. Cardoso CML, Pereira MO, Moreira DA, Tibães HBB, Ramos FRS, Brito MJM. Moral distress in family health strategy: experiences expressed by daily life. Rev Esc Enferm USP [Internet]. 2016 [cited 2017 Jan 10];50(n.esp):89-95. Available from: http://dx.doi.org/10.1590/ S0080-623420160000300013

24. Monteschio CAC, Gaíva MAM, Moreira MDS. The nurse faced with early weaning in child nursing consultations. Rev Bras Enferm [Internet]. 2015 [cited 2017 Jan 28];68(5):869-75. Available from: http://dx.doi.org/10.1590/0034-7167.2015680515i

25. Bortolini GA, Vitolo MR, Gubert MB, Santos LMP. Early cow's milk consumption among Brazilian children: results of a national survey. J Pediatr [Internet]. 2013 [cited 2016 Dec 18];89(6): 608-13. Available from: https://doi.org/10.1016/j.jped.2013.04.003

26. Miranda A, Contreras S. El cuidado enfermero como problema ético: concepto y principios prácticos aplicados al acto de cuidado. Rev Bras Enferm [Internet]. 2014 [cited 2017 Feb 16];67(6):873-80. Available from: http://dx.doi.org/10.1590/0034-7167.2014670602 